\title{
PENERAPAN PRINSIP KEPENTINGAN UMUM TERHADAP KEBERADAAN TANAH TERLANTAR DI INDONESIA
}

\author{
Oleh: \\ Nyoman Arif Budiman ${ }^{1}$
}

\begin{abstract}
This journal shall be entitled as "Implementation Of Public Interest Principles To Neglected Land In Indonesia". The existence of the land on earth must be beneficial both for the welfare and happiness that has it and for the people and the state. The purpose of this study is to know and understand the absolute limits of property rights to land; and want to understand the relationship between the principle of public interest in land. The method in this research is normative by using conceptual approach and statute approach. This journal's preparation is done by legal research, and the approach method being used in this journal shall be used is the combination of the statute approach and the conceptual approach. The result of this research is the essence of the principle of public interest to the land is to create development based on the principle of humanity in the balance as stipulated in the 1945 Constitution of the Republic of Indonesia. The exemption of land rights is caused by public and private interest with the provision of compensation and guided by the principle of musyawarah. While the revocation of land rights is the spirit of the provisions of Article 18 of the Basic Agrarian Laws states that for the interest of the state and the state and the common interest of the people of the right to land may be revoked by compensation. The legal effort that a third party can take to exploit the state land (abandoned land) is to apply the right to the government (Provincial or Regency / City Land Office).
\end{abstract}

Keywords: General Interest Principles, Revocation of Land Rights, Neglected Land.

\begin{abstract}
Abstrak
Jurnal ini mengambil judul "Penerapan Prinsip Kepentingan Umum Terhadap Tanah Terlantar. Keberadaan atas tanah di muka bumi ini harus bermanfaat baik bagi kesejahteraan dan kebahagiaan pemiliknya pemiliknya maupun bagi masyarakat dan negara. Tujuan dari penelitian ini ialah ingin mengetahui dan memahami batas-batas absolut dari hak milik terhadap tanah; dan ingin memahami hubungan antara hak milik atas tanah dan prinsip kepentingan umum atas tanah. Jurnal ini mengangkat permasalahan yang juga menjadi tujuan penulisan yaitu apa hakikat kepentingan umum atas tanah dan apa upaya hukum yang dapat dilakukan oleh pihak ketiga terhadap tanah terlantar. Penyusunan jurnal ini dilakukan dengan tipe penelitian normatifdan menggunakan pendekatan peraturan perundang-undangan dan pendekatan konsep. Hasil dari penelitian ini adalah

1 Program Studi Magister Ilmu Hukum Universitas Airlangga, Surabaya, Jawa Timur, email: arifbudimanbaristha@yahoo.com
\end{abstract}


Hakekat dari prinsip kepentingan umum terhadap tanah ialah untuk menciptakan pembangunan yang berlandaskan asas perikemanusiaan dalam keseimbangan sebagaimana diatur dalam UUD NRI tahun 1945. Pembebasan hak atas tanah disebabkan oleh kepentingan umum dan swasta dengan pemberian ganti rugi dan berpedoman pada asas musyawarah. Sedangkan pencabutan hak atas tanah merupakan semangat dari ketentuan Pasal 18 UUPA menggariskan bahwa untuk kepentingan bangsa dan negara serta kepentingan bersama (hanya untuk kepentingan umum) dari rakyat hak atas tanah dapat dicabut dengan memberikan ganti kerugian. Upaya hukum yang dapat dilakukan pihak ketiga untuk dapat memanfaatkan tanah negara (tanah terlantar) ialah melakukan permohonan hak kepada pemerintah (Kantor Pertanahan Provinsi atau Kabupaten/Kota).

\section{Kata Kunci: Prinsip Kepentingan Umum, Pencabutan Hak Atas Tanah, Tanah Terlantar.}

\section{PENDAHULUAN}

Seluruh bumi, air dan ruang angkasa, adalah termasuk kekayaan alam yang terkandung di dalamnya dalam wilayah Negara Republik Indonesia sebagai karunia Tuhan Yang Maha Esa dan merupakan kekayaan nasional. Bumi, air, dan ruang angkasa termasuk kekayaan alam yang terkandung di dalamnya itu pada tingkatan tertinggi dikuasai oleh negara, sebagai organisasi oleh seluruh rakyat. $^{2}$

Tanah merupakan salah satu hal terpenting bagi hidup dan kehidupan bagi manusia. Tanah bagi kehidupan manusia mempunyai peran yang sangat penting. Tanah tidak saja dibutuhkan sebagai tempat tinggal, tapi juga sebagai tempat untuk lapangan pekerjaan dalam menunjang kehidupan keluarga. ${ }^{3}$ Di atas tanah pula manusia

2 Urip Santoso, Pendaftaran dan Peralihan Hak atas Tanah, Cet. I, Kencana Prenada Media, Jakarta, 2015 hlm. 205.

3 Eman, Pengadaan Tanah bagi Pelaksanaan Pembangunan bagi Kepentingan Umum, Majalah YURIDIKA, Volume 23, No 1, Fakultas Hukum Universitas Airlangga, bisa membangun rumah sebagai tempat tinggal dan membangun berbagai bangunan lainnya untuk perkantoran dan sebagainya. Pendek kata, segala aktivitas manusia apapun bentuknya tidak akan lepas tidak akan lepas dari kebutuhan akan tanah. ${ }^{4}$

Fungsi dan peran tanah dalam berbagai sektor kehidupan manusia memiliki empat aspek yang sangat strategis, yaitu aspek ekonomi, politik, hukum, dan sosial. ${ }^{5}$ Keempat aspek tersebut merupakan isu sentral yang terkait sebagai kesatuan yang terintegrasi dalam pengambilan proses kebijakan hukum pertanahan yang dilakukan oleh pemerintah. ${ }^{6}$ Untuk dapat mewujudkan keteraturan dan ketertiban maka perlu di bentuk

Surabaya, Januari - April 2008, hlm. 50.

4 Adrian Sutedi, Implementasi Prinsip Kepentingan Umum (Dalam Pengadaan Tanah Untuk Pembangunan), Cet. II, Sinar Grafika, Jakarta, 2008, hlm.45.

5 Y. Wartaya Wiguna, SJ, Tanah Sumber Nilai Hidup, Cet.. I, Kanisius, Jakarta, 2004, hlm. 21.

6 H. Idham, Konsolidasi Tanah Perkotaan dalam Perspektif Otonomi Daerah, Cet. I, Alumni, Bandung, 2004, hlm.1. 
peraturan perundang-undangan yang jelas dan tegas.

Pengaturan tentang tanah sebagai sarana untuk memenuhi kebutuhan dasar manusia dapat dilihat dalam berbagai pengaturan perundangundang.Kesadaranakanartipentingnya fungsi tanah terkait dengan hak asasi manusia (HAM) mulai dirasakan semenjak era reformasi. ${ }^{7}$ Di awali dengan terbitnya Undang-Undang Nomor 39 Tahun 1999 tentang Hak Asasi Manusia, arti penting hak untuk hidup, mempertahankan hidup dan meningkatkan taraf kehidupan (Pasal 9 ayat (1)) itu memerlukan ketersediaan tanah untuk pemenuhan hak atas kesejahteraan berupa milik, yang dapat dimiliki untuk diri sendiri maupun bersama-sama dengan orang lain untuk pengembangan dirinya bersama-sama dengan masyarakat. Hak milik yang mempunyai fungsi sosial itu dilindungi dari tindakan sewenang-wenang dari pihak lain, sehingga ketika hak milik itu diperlukan untuk kepentingan umum maka harus diberikan ganti kerugian yang wajar dan segera dilaksanakan sesuai dengan ketentuan peraturan perundang-undangan (Pasal 36 dan Pasal 37). ${ }^{8}$

Prinsip penghormatan terhadap milikpribadiinikemudian dicantumkan

7 Rosmidah, Pengakuan Hukum Terhadap Hak Ulayat Masyarakat Hukum Adat dan Hmabatan Implementasinya, Jurnal Ilmu Hukum, Volume 3 no. 1, Universitas Jambi, september, 2017, hlm. 8 .

8 Maria S.W. Sumardjono, Tanah Dalam Perspektif Hak Ekonomi, Sosial, dan Budaya, Cet. II, Kompas Media Nusantara, Jakarta, 2009, hlm. 3 . dalam Undang-Undang Dasar 1945 perubahan Kedua yakni dalam Pasal 28 A, 28 H ayat (4) dan Pasal 28 j ayat (2). Secara khusus hak atas tanah yang merupakan hak ekonomi, sosial dan budaya itu diatur dalam UndangUndang 11 Tahun 2005 tentang Pengesahan Internasional Convenant on Economic, Social and Cultural Rights (Konvenan Internasional tentang Hak-hak Ekonomi, Sosial, dan Budaya).

Dalam kaitannya dengan ketersediaan tanah, dalam Pasal 11 ayat (1) UU No. 11 Tahun 2005 disebutkan tentang hak setiap orang atas standar kehidupan yang layak bagi diri sendiri dan keluarga, termasuk hak untuk memperoleh pangan, sandang dan perumahan, dan atas perbaikan kondisi hidup secara terus-menerus. Selanjutnya dalam ayat (2) ditegaskan tentang pengakuan terhadap hak mendasar dari setiap orang untuk bebas dari kelaparan, dan untuk mendukung hak itu negara harus mengambil langkah-langkah yang diperlakukan untuk meningkatkan cara-cara produksi, konsumsi dan distribusi pangan sehingga mencapai perkembangan dan pemanfaatan sumber daya alam yang efisien.

Berbagai peraturan perundangundangannasionalbaiksecaralangsung atau tidak langsung memberikan jaminan bagi terwujudnyahak-hak bagi orang perorangan maupun kelompok tersebut sebagaimana diamanatkan dalam Pancasila dan Pasal 33 ayat 
(3) UUD NRI 1945. Untuk mewujud hak-hak tersebut maka diterbitkannya Undang-Undang Nomor 5 Tahun 1960 tentang Pokok-Pokok Agraria (selanjutnya disingkat UUPA). ${ }^{9}$

UUPA adalah undang-undang yang mengatur asas-asas serta soalsoal pokok dalam garis besar mengenai pertanahan. Sebagai peraturan perundangan yang dibentuk sebagai penyempurnaan perundang-undangan sebelumnya yang dianggap kurang mampu memberikan keadilan bagi masyarakat pribumi sebagai pemilik asli tanah, air, ruang angkasa serta kekayaan alam yang terkandung di seluruh Indonesia. Tujuan utamanya tercantum dalam Pancasila dan Undang-Undang Dasar Negara Republik Indonesia Tahun 1945, yaitu menciptakan kemakmuran yang adil dan merata.

Pasal 33 ayat (3) UUD 1945 yang menjadi landasan UUPA memberikan kemungkinan bagi negara untuk memberikan hak atas tanah kepada perorangan dan badan hukum sesuai keperluannya. Dengan demikian, pemilikan dan penguasaan tanah yang melampaui batas kewajaran yang bertentangan dengan asas land reform yang bertujuan untuk mewujudkan keadilan sosial berupa pemerataan tanah sebagaimana dijabarkan oleh Pasal 7 dan 17 UUPA.

Pasal 2 ayat (2) UUPA menetapkan bahwa Negara memiliki wewenang hak menguasai atas bumi,

9 Ibid., hlm. 4. air, dan ruang angkasa, termasuk kekayaan alam yang terkandung di dalamnya, yaitu:

a. Mengaturdanmenyelenggarakan peruntukan, penggunaan, persediaan, dan pemeliharaan bumi, air, dan ruang angkasa;

b. Menentukan dan mengatur hubungan-hubungan hukum antara orang-orang dengan bumi dan ruang angkasa;

c. Menentukan dan mengatur hubungan-hubungan hukum antara orang-orang dan perbuatan-perbuatan hukum yang mengenai bumi, air, dan ruang angkasa.

Pada awal berlakunya UUPA sudah mulai terasa adanya gejala ketimpangan kepemilikan dan penguasaan tanah. Perbandingan antara ketersediaan tanah sebagai daya alam yang langka di satu sisi, dan pertambahan jumlah penduduk dengan berbagai penemuan kebutuhannyaakan tanah di sisi lain, tidak mudah dicari titik temunya. Berbagai macam contoh permasalahan tanah yang sering terjadi ialah: sertifikat ganda, ukuran tanah tidak sesuai dengan sertifikat tanah dan permasalahan yang akhir-akhir ini menimbulkan kerugian yang sangat besar dan bertentangan dengan fungsi dari tanah ialah masalah penelantaran tanah baik berstatus hak milik, hak guna usaha, dan hak guna bangunan.

UUPA berusaha meminimalkan ketimpangan dalam akses perolehan tanah dan pemanfaatan tanah 
itu dengan membuat ketentuan tentang pembatasan pemilikan dan pembatasan tanah, khususnya tanah pertanian dalam Pasal 7, dan Pasal 17 UUPA. Hal kemudian ditindak lanjut dengan adanya UU Nomor 56 Tahun 1960 tentang Penetapan Luas Tanah Pertanian. Dalam Pasal 12 UU 56 Tahun 1960 , yang pada intinya mengatur mengenai pembatasan penggunaan terhadap tanah adalah hal yang tidak penting. Pengaturan tersebut disebabkan, karena tanah sangat berhubungan dengan banyak orang.

Bila ketentuan Pasal 12 UU No 56 tahun 1960 dicermati, maka ukuran maksimum untuk tanah bangunan didasarkan pada luas dan jumlah tanah. Hal ini berarti bahwa bila sudah ditentukan maksimum untuk daerah tertentu seyogianya dibedakan antara daerah yang mempunyai arti strategis bagi pembangunan dan daerah kegiatan pembangunannya belum berlaku secara intensive, maka kriterianya dapat dipilih antara :

1. Menentukan batas luas tertentu (baik untuk tanah yang sudah ada bangunan maupun yang belum ada), misalnya $5.000 \mathrm{~m}^{2}$ bagi daerah strategis dan 10.000 $\mathrm{m}^{2}$ bagi daerah lain dengan penentuan bidang tanah sekitar 5 atau 10 bidang atau;

2. Hanya menentukan batas luas tertentu tanpa menentukan bidang tanahnya. Alternative kedua tampaknya lebih fleksibel mengingat adanya kemungkinan penetapan luas kapling tanah yang diatur oleh pemerintah daerah yang bersangkutan untuk pembangunan.

Keadaan yang dikemukakan 30 tahun yang lalu jelas sudah berubah. Bahwakeadaaninisudahdianggapperlu ditangani, tampak dari pembuatannya dalam berbagai Ketetapan MPR, yang diawali dengan TAP RI No. IV/ MPR/1978 yang mengatur tentang perlunya menata kembali penggunaan, penguasaan dan pemilikan tanah untuk mewujudkan keadilan sosial. Hal yang sama ditetapkan lagi dalam TAP MPR RI No. II/MPR/1988. terakhir dengan TAP MPR RI No. II/MPR/1993 secara eksplisit disebutkan tentang pentingnya pembatasan pemilikan dan penguasaan tanah ini, antara berikut:

"Penataan penggunaan tanah perlu memperhatikan hakhak rakyat atas tanah, batas maksimum kepemilikan tanah pertanian dan perkotaan serta mencegah penelantaran tanah termasuk berbagai upaya untuk mencegah pemutusan, penguasaan yang merugikan kepentingan rakyat." ${ }^{\text {"10 }}$

Bahwa yang dibatasi itu tidak terbatas pada kepemilikan tanah dan bangunan saja, melainkan juga penguasaannya, karena penguasaan tanah mempunyai jangkauan pengertian yang lebih luas, yakni $10 \quad$ Ibid, hlm. 13. 
meliputi penguasaan yang didasarkan pada suatu hak maupun penguasaan yang didasarkan pada suatu kuasa yang pada kenyataan memberikan wewenang untuk melakukan perbuatan hukum selayaknya seseorang yang mempunyai hak.

Pemberian atas hak tentunya melihat status, sejauh manakah hak itu akan diberikan dengan melihat kegunaan dan daripada penerimaan hak itu, walaupun kita tahu bahwa hak-hak atas tanah apapun yang melekat di atasnya fungsi sosial, yang artinya apabila kepentingan umum lebih menghendaki dapat saja haknya dicabut. Akan tetapi seyogianya pemberian hak ini akan lebih jelas menjamin rasa aman dan pemegang hak. ${ }^{11}$

Penjelasan angka II (4) UUPA, telah menggariskan bahwa hak atas tanah apapun yang ada pada seseorang, tidaklah dapat dibenarkan, bahwa tanahnya itu akan dipergunakan (atau tidak dipergunakan) semata-mata untuk kepentingan pribadinya, apalagi jika hal itu menimbulkan kerugian bagi masyarakat. Penggunaan tanah harus disesuaikan dengan keadaannya dan sifat daripada haknya, hingga bermanfaat baik bagi kesejahteraan dan kebahagiaan yang mempunyainya maupun bagi masyarakat dan negara. Makapenegasan tersebutharus disikapi bahwa pemilik tanah secara luas dan penelantaran tanah yang dilakukan

11 Soedharyo Soimin, Status Hakdan Pembebasan Tanah, Cet. II, Sinar Grafika, Jakarta, 2008, hlm. 17. oleh pemiliknya tidak diupayakan atau secara produktif telah menyalahi fungsi sosial sehingga wajar kalau negara dapat mengakhiri atau hakhaknya kembali kepada pemegang "hak menguasai negara".

Dalam penelitian ini penulis menggunakan bahan hukum berupa peraturan perundang-undangan dan literatur hukum yang berkaitan dengan permasalahan yang dibahas. Penulis juga menyadari bahwa penelitian ini memiliki beberapa kemiripan dengan penelitian tetapi penulisan ini tentu memiliki perbedaan dalam hal pembahasan pada penelitian ini. Adapun penelitian lain yang terkait dengan Penerapan Prinsip Kepentingan Umum Terhadap Tanah Terlantar, antara lain:

1. Judul Penelitian : Penggunaan Kuasa Menjual Di Dalam Peralihan Hak Milik Atas Tanah Melalui Jual-Beli. Dengan tujuan penelitian yaitu untuk memberikan gambaran tentang sahnya peralihan hak milik atas tanah melalui jual-beli, secara khusus untuk menelaah apakah penggunaan kuasa mutlak di dalam peralihan hak milik atas tanah melalui jual-beli adalah legal/sah secara hukum atau sebaliknya. ${ }^{12}$

12 Adnyana, Penggunaan Kuasa Menjual di dalam Peralihan Hak Milik Atas Tanah Melalui Jual-Beli, Jurnal Magister Hukum Udayana (Udayana Master Law Journal), Vol.4, No.1, Edisi Mei 2015,https://ojs.unud.ac.id/index. $\mathrm{php} / \mathrm{jmhu} /$ article/view/13050, diakses tanggal 20 Oktober 2017. 
2. Judul Penelitian: PrinsipPrinsip Pengelolaan Tanah Wakaf Guna Peningkatan Kesejahteraan Masyarakat. Dengan tujuan penelitian yaitu: untuk memahami terkait prinsipprinsip dalam pengelolaan dan pemanfaatan tanah wakaf guna untuk peningkatan kesejahteraan masyarakat. ${ }^{13}$

3. Perlindungan Hukum Bagi Pemegang Sertifikat Hak Milik Atas Tanah dalam Ketentuan Pasal 32 Ayat (2) PP No. 24 Tahun 1997. Dengan tujuan penelitian yaitu untuk mengkaji kepastian hukum sertifikat hak milik atas tanah dikaitkan dengan Pasal 32 ayat (2) PP No. 24/1997, berkaitan dengan lewatnya batas waktu lima tahun dalam peraturan tersebut; Untuk mengkaji lebih dalam tentang perlindungan hukum bagi pemegang sertifikat hak milik atas tanah berkaitan dengan Pasal 32 ayat (2) PP No. 24/1997 tentang Pendaftaran Tanah. ${ }^{14}$

13 Suhirman, Prinsip-Prinsip Pengelolaan Pemanfaatan Tanah Wakaf Guna Peningkatan Kesejahteraan Masyarakat, Jurnal Magister Ilmu Hukum Udayana (Udayana Master Law Journal), Vol. 4, No. 2 : 252-262, Edisi Juli 2015, https://ojs.unud.ac.id/index.php/ jmhu/article/view/17521, diakses tanggal 21 Oktober 2017.

14 Putu Ade Harriestha Martana, Perlindungan Hukum Bagi Pemegang Sertifikat Hak Milik Atas Tanah dalam Ketentuan Pasal 32 Ayat (2) PP No. 24 Tahun 1997, Jurnal Magister Hukum Udayana (Udayana Master Law Journal), Vol. 3 No. 1 Edisi Maret 2014 https://ojs.unud. ac.id/index.php/jmhu/article/view/8448, diakses tanggal 21 Oktober 2017.
Adapun tujuan dari penelitian yang dilakukan penulis ini ialah ingin mengetahui dan memahami batas-batas absolut dari hak milik yang dimiliki oleh individu terhadap tanah; dan ingin memahami hubungan antara prinsip kepentingan umum atas tanah.

\section{METODE PENELITIAN}

Tipe penelitian yang digunakan dalam menyusun jurnal ini adalah tipe Penelitian Hukum karena penelitian ini dilakukan berdasarkan aturan-aturan hukum yang ditelaah guna menemukan solusi dari permasalahan isu hukum yang dihadapi dalam penelitian hukum ini. $^{15}$

Pendekatan masalah yang digunakan dalam penulisan tesis ini adalah menggunakan pendekatan perundang-undangan

(statute approach) dan pendekatan konsep (conceptual approach). ${ }^{16}$ Pendekatan perundang-undangan

(statute approach) ini dilakukan dengan melakukan penelahan mendalam terhadap peraturan perundangundangan yang berkaitan dengan kasus ini. Pendekatan konsep (conceptual approach)merupakan pendekatanyang didasarkan pada buku-buku ataupun literatur yang menjelaskan tentang hal-hal atau konsep-konsep yang dapat membantu dalam menganalisis kasus

15 Peter Mahmud Marzuki, Penelitian Hukum, Kencana Perdana Media, Surabaya, 2014, hlm. 60 .

16 Ibid.,.hlm. 93 
ini, seperti Konsep kepentingan umum terhadap tanah dan konsep tanah terlantar.

Berdasarkan latar belakang dapat tadi dapat dikemukakan rumusan masalah yang sekaligus menjadi tujuan dalam makalah ini yaitu untuk mengkaji dan menganalisis hakikat dari prinsip kepentingan umum atas tanah dan upaya hukum yang dapat dilakukan oleh pihak ketiga terhadap tanah terlantar.

III. HASIL DAN PEMBAHASAN 3.1. Hakikat Kepentingan Umum Atas Tanah

Kehidupan komunitas masyarakat tertentu, pada dasarnya doktirn yang berlaku adalah doktrin yang mewajibkan setiap warga negara sebagai individu untuk selalu mengalah demi kesejahteraan orang banyak di komunitas daerah lokal nya. Artinya dengan kesediaannya untuk mengalah dan rela berkorban demi kepentingan umum, yang dalam arti konkret sebagai pengorbanan untuk orang banyak, mereka dapat diterima dan diberi tempat di tengah kehidupan komunitas nya. ${ }^{17}$

Dalam Pasal 9 ayat (2) UUPA, menguasai dan menggunakan tanah secara individual dimungkinkan dan diperbolehkan, hal itu ditegaskan dalam Pasal 4 ayat (1), dan Pasal 21, 29, 36, 42, dan 45 UUPA, yang berisikan persyaratan pemegangan hak atas tanah juga menunjukkan

17 Adrian Sutedi, Op., Cit., hlm. 84. prinsip penguasaan dan penggunaan tanah secara individual. Namun, hakhak atas tanah yang individu dan bersifat pribadi tersebut dalam UUPA terkandung unsur kebersamaan atau unsur kemasyarakatan tersebut ada pada tiap hak atas tanah, karena semua hak atas tanah secara langsung ataupun tidak langsung bersumber dari Hak Bangsa, yang merupakan hak bersama. Persoalan yang masih dihadapi sehubungan dengan pelaksanaan kepentingan umum adalah menentukan titik keseimbangan antara kepentingan umum dan kepentingan pribadi di dalam pembangunan. ${ }^{18}$

$\begin{array}{ccr}\text { Menurut } & \text { Jhon } & \text { Salindeho, } \\ \text { kepentingan } & \text { umum } & \text { sebagai }\end{array}$

kepentingan bangsa dan negara serta kepentingan bersama dari rakyat, dengan tetap memperhatikan segi-segi politik, psikologis dan Hankamnas atas dasar asas-asas pembangunan nasional dengan mengindahkan ketahanan nasional sebagai wawasan nusantara. ${ }^{19}$

Di sisi lain, pengertian umum untuk "kepentingan masyarakat", kata ini mempunyai arti bias seandainya ditafsirkan secara legalistic formalistic. Oleh karena itu, istilah ini harus ditafsir secara teologis (sosiologis), yakni menafsirkan istilah masyarakat menurut keadaan masyarakat indonesia. Melihat dari

18 A. A. Oka Mahendra, Menguak Masalah Hukum, Demokrasi dan Pertanahan, Cet. I, Sinar Harapan, Jakarta, 1996, hlm. 256.

19 Jhon Salindeho, Masalah Tanah Dalam Pembangunan, Cet. II, Sinar Grafika, Jakarta, 1993, hlm. 40. 
sifat masyarakat yaitu gesellschaft mempunyai ciri-ciri hubungan individual dengan individu yang lainnya bersifat pamrih dan rasional serta mempertimbangkan untung rugi. Masyarakat terbagi-bagi berdasarkan kelas ekonomi, yakni ekonomi atas, menengah dan bawah. Perpaduan dalam komunitas masyarakat ini bersifat atomistis yang mempunyai arti bahwa masyarakat digambarkan sebagai perkumpulan individu yang satu dengan lainnya relatif tidak ada perekatannya. $^{20}$ Jadi bentuk kepentingan umum pada masyarakat gesellschaft bersifat komunal dan agraris pedesaan mempunyai karakter yang berbeda dengan perkotaan.

Secara terminilogi kepentingan umum "untuk masyarakat banyak" secara sekilas sudah cukupjelas, namun kalau dipahami dengan berempati di lapangan akan timbul permasalahan. Kata "banyak" diatas mempunyai maksud berupa jumlah. Mungkinklah yang dimaksud rakyat banyak tersebut adalah perbandingan antara rakyat yang dibebaskan tanahnya untuk kepentingan umum harus lebih banyak dibandingkan dengan rakyat penerima manfaat kegiatan untuk kepentingan umum yang direncanakan. Tujuan dari kepentingan umum ialah untuk meningkatkan kesejahteraan masyarakat umum dan tidak mencari keuntungan atau laba. Kecuali itu apa yang disebut kepentingan umum itu menyangkut kepentingan bangsa 20 M. Munandar, Dinamika Masyarakat Transisi, Pustaka Pelajar, Jakarta,1998, hlm. 45. dan negara, pelayanan umum dalam masyarakat luas, rakyat banyak dan pembangunan. ${ }^{21}$

Menentukan kriteria atau ukuran kepentingan umum sangatlah tidak mudah, karena kepentingan umum itu sendiri adalah konsep yang kabur sehingga sulit untuk didefinisikan. ${ }^{22}$ Tidak setiap kepentingan pemerintah selalu bertujuan untuk kepentingan umum, misalnya pembangunan pelabuhan, memang itu kepentingan pemerintah tetapi bukan kepentingan umum, karena pada akhirnya akan dikelola oleh BUMN yang selalu mencari keuntungan untuk memberikan pendapatan bagi negara dan BUMN sendiri. Di sisi lain hal ini tidak memberikan manfaat bagi masyarakat luas dan rakyat.

Agar kepentingan umum tidak berpeluang untuk ditafsirkan sesuai hendak pemerintah, diperlukan adanya kriteria yang harus dipatuti oleh pemerintah dan dapat dipertanggung jawabkan secara hukum. Kriteria kepentingan umum yang baik dapat ditetapkan jika berpedoman pada syarat-syarat universal yang harus ada dalam kepentingan umum. Syarat utama dan mendasari semua syarat kepentingan umum adalah cita-cita dan tujuan negara yang telah diatur di dalam pembukaan UUD NRI 1945. Cita-cita

21 Sudikno Mertokusumo, Mengenal Hukum, Cet. III, Liberty, Yogyakarta, 2002, hlm. 45.

22 Winner Sitorus, Kepentingan Umum dalam Perlindungan Paten, Majalah YURIDIKA, Volume 29, No 1, Fakultas Hukum Universitas Airlangga, Surabaya, Januari - April 2014, hlm. 44 
negara adalah mewujudkan rakyat, bangsa dan negara yang merdeka, bersatu, berdaulat adil dan makmur. Sedangkan yang menjadi tujuan negara adalah melindungi rakyat, segenap bangsa, dan tumpah darah, memajukan kesejahteraan umum dan mencerdaskan kehidupan bangsa. Cita dan tujuan negara tersebut menjadi penentu negara untuk mewujudkan keadilan, persatuan dan kesatuan, kemakmuran dan kesejahteraan, serta melindungi rakyat Indonesia.

Berdasarkan Peraturan Presiden Nomor 36 Tahun 2005 disebutkan ciri-ciri kegiatan untuk kepentingan umum, yakni

"kepentingan umum adalah kegiatan pembangunan yang dimiliki, dilakukan oleh pemerintah dan bersifat non profit.'

Ada tiga prinsip yang dapat ditarik kesimpulan bahwa suatu kegiatan benar-benar untuk kepentingan umum, yaitu:

1. Kegiatan tersebut benar-benar dimiliki oleh pemerintah.

Kalimat ini mengandung batasan bahwa kegiatan untuk kepentingan umum tidak dapat dimiliki oleh perorangan ataupun swasta. dengan kata lain swasta dan perorangan tidak memiliki jenis-jenis kegiatan untuk kepentingan umum yang membutuhkan pembebasan tanah-tanah hak maupun negara.
2. Kegiatan pembangunan terkait dilakukan oleh pemerintah.

Kalimat ini memberikan batasan bahwa proses pelaksanaan dan pengelolaan suatu kegiatan untuk kepentingan umum hanya dapat diperankan oleh pemerintah.

3. Tidak mencari keuntungan

Kalimat ini membatasi tentang fungsi suatu kegiatan untuk kepentingan umum sehingga benar-benar berbeda dengan kepentingan swasta yang bertujuan untuk mencari keuntungan sehingga terkualifikasi bahwa kegiatan untuk kepentingan umum sama sekali tidak boleh mencari keuntungan.

Kriteria kepentingan umum di atas agar secara efektif dapat dilaksanakan di lapangan tentunya harus memenuhi kriteria sifat, karena bentuk, dan kriteria karakteristik/ciriciri, yakni: ${ }^{23}$

1. Penerapan untuk kriteria sifat suatu kegiatan untuk kepentingan umum agar memiliki kualifikasi untuk kepentingan umum harus memenuhi salah satu sifat dari beberapa sifat yang telah ditentukan dalam daftar sifat kepentingan sebagaimana tercantum dalam Pasal 1 UndangUndang 20 Tahun 1961. Jadi penggunaan daftar sifat tersebut bersifat wajib alternatif.

23 Adrian Sutendi, Op., Cit., hlm. 76. 
2. Penerapan untuk kriteria bentuk suatu kegiatan untuk kepentingan umum agar mempunyai kualifikasi sebagai kegiatan untuk kepentingan umum harus memenuhi salah satu syarat bentuk kepentingan umum sebagaimana ditentukan dalam bentuk kegiatan kepentingan umum tersebut sebagaimana tercantum dalam Pasal 2 Inpres 1973 dan Pasal 5 Peraturan Presiden No. 36 Tahun 2005.

3. Penerapan untuk kriteria ciriciri kepentingan umum agar memenuhi kualifikasi ciri-ciri kepentingan umum sehingga benar-benar berbeda dengan kepentingan umum, yakni bahwa kegiatan tersebut benarbenar dimiliki pemerintah, dikelola oleh pemerintah dan tidak untuk mencari keuntungan, sebagaimana diatur dalam Pasal 5 ayat (2) Peraturan Presiden Nomor 36 Tahun 2005.

Bila mana pencabutan hak tersebut dilakukan tanpa mengindahkan, persyaratanpersyaratan, maka perbuatan yang dilakukan oleh pemerintah dapat dinilai sebagai perbuatan yang melanggar hukum (onrectmatige overheidsdaad) atau sebagai penyalahgunaan wewenang. untuk memenuhi amanat dari ketentuan Pasal 18 UUPA, pemerintah pada tahun 1969 telah menetapkan Undang-Undang Nomor 20 Tahun 1968 tentang Pencabutan
Hak-Hak Atas Tanah dan Benda diatasnya. Ketentuan dalam Pasal 18 UUPA menggariskan bahwa untuk kepentingan bangsa dan negara serta kepentingan bersama dari rakyat hak atas tanah dapat dicabut dengan memberikan ganti kerugian. ${ }^{24}$

Penetapan ganti rugi yang diberikan harus mempertimbangkan statushakatas tanahyangbersangkutan. Jika statusnya Hak milik maka harus menjadikan pertimbangan dan perkiraan yang akurat terhadap harga ganti ruginya. Artinya harus lebih besar dari hak-hak atas tanah lainnya seperti HGB dan HGU. Ganti rugi tidak saja diberikan kepadanya tanahnya, tetapi juga harus memperhitungkan benda-benda yang ada di atas tanah hak milik, seperti bangunan, pagar, tanaman, listrik, telepon, pipa air, air ledeng dan lainnya. Ganti rugi bukan hanya diberikan kepada pemilik tanah, tetapi juga kepada mereka yang sedang menyewa tanah dan atau rumah atau menggarap tanah yang bersangkutan.

Prinsip-prinsip dasar ganti rugi karena pencabutan hak yang merupakan pedoman adalah:

1. Harga pasar yang layak (fair marketvalue),yaknipemanfaatan yang tertinggi dan terbaik.

2. Doktrin fasilitas, yakni memberikan tanah pengganti apabila pemilik tanah sukar memperoleh tanah pengganti

24 Marmin M. Roosadijo, Tinjauan Pencabutan Hak-Hak Atas Tanah dan Benda-Benda yang Ada di Atasnya, Cet. I, Ghalia Indonesia, Jakarta, 1979, hlm. 17. 
karena harga tanah pengganti mahal.

3. Prinsip keadilan. ${ }^{25}$

Hal ini sejalan dengan pandangan

Telders, bahwa yang berhak untuk penggantian kerugian adalah pemilik, penyewa dan pachter $^{26}$ Schenk memperjelas bahwa ganti rugi itu sepenuhnya meliputi: ${ }^{27}$

1. Setiap kerugian akibat langsung dari pencabutan hak yang harus diganti sepenuhnya.

2. Kerugian disebabkan sisa yang tidak dicabut haknya menjadi berkurang nilainya.

3. Kerugian karena tidak dapat mempergunakan benda tersebut, tau karena kehilangan penghasilan.

4. Kerugian karena mencari tempat usaha lain sebagai penggantinya.

Boedi Harsono juga berpendapat bahwa kebijakan mengenai pemberian ganti-rugi sebenarnya tidaklah terbatas pada penggantian nilai tanahbangunan, dan tanam-tanaman, tetapi juga seharusnya meliputi penilaian kerugian yang bersifat immaterial dan

25 Munir Fuady, Hukum Bisnis dalam Teori dan Praktik, Cet. II, Citra Aditya Bakti, Bandung, 1999, hlm. 314

26 A.P. Parlindungan, Pencabutan, dan Pembebasan Hak Atas Tanah Suatu Studi Perbandingan, Cet. I, Mandar Maju, 1993, h. 50 dikutip dari Teders C.H., Schadeloosstelling voor Onteingenings, 1968, hlm. 25.

27 Ibid., dikutip dari W. Schenk, Onteingening, Serie Recht en Praktijk, 1975, hlm. 60. kerugian yang timbul, seperti kegiatan usahanya, akibat perpindahan ke tempat lain, jumlah pelanggan dan keuntungan yang berkurang. ${ }^{28}$

Pemberian ganti kerugian dapat diberikan dalam berupa uang, tanah pengganti, pemukiman kembali, kepemilikan saham, bentuk lain yang disetujui para pihak, namun yang menjadi persoalan dalam jika pemegang hak atas tanah tidak menyetujui segala bentuk dan jenis ganti rugi pada intinya adalah tidak mau melakukan pelepasan hak walaupun ada ganti rugi. maka dalam hal ini pemegang hak atas tanah dapat menolak dan mengajukan keberatan kepada pengadilan negeri setempat dalam waktu paling lama 14 hari kerja setelah musyawarah penetapan ganti rugi dilakukan. ${ }^{29}$

Setelah pengadilan negeri memutus bentuk dan jenis ganti rugi tetapi pemegang hak atas tanah tetap menolak ganti kerugian tersebut maka pemegang hak atas tanah dapat mengajukan kasasi kepada Mahkamah Agung RI. Dengan demikian, maka putusan Pengadilan Negeri atau Mahkamah Agung yang telah memperoleh kekuatan hukum

28 Boedi Harsono, "Masalah Kerangka Persoalan dan Pokok-Pokok Kebijaksanaan Pertanahan Nasional, dalam BF Sihombing, Pergeseran Kebijakan Pengadaan Tanah untuk Kepentingan Pemerintahan dan Swasta (Studi Kasus Pengaturan Pemilikan, Pengusaha Tanah di Provinsi DKI Jakarta), Disertasi, Universitas Indonesia, Jakarta, 2004.

29 Pasal 38 ayat 1 UU No. 2 Tahun 2012, keberadaan pasal ini bertujuan untuk melindungi hak pribadi yang dimiliki oleh pemilik / pemegang hak atas tanah. 
tetap menjadi dasar pembayaran ganti kerugian kepada pihak yang mengajukan gugatan, artinya bahwa dalam proses di Pengadilan ini, pola musyawarah dalam penetapan ganti rugi tidaklah berhasil mencapai kesepakatan. ${ }^{30}$

\subsubsection{Tanah Terlantar}

Definisi tanah terlantar tidak diatur di dalam Peraturan Pemerintah Republik Indonesia Nomor 11 Tahun 2010 tentang Penertiban dan Pendayagunaan Tanah Terlantar (selanjutnya disingkat menjadi PP No.11 tahun 2010"), tetapi diatur di dalam Pasal 1 angka 6 Peraturan Kepala Badan Pertanahan Nasional Republik Indonesia Nomor 4 tahun 2010 tentang Tata Cara Penertiban Tanah Terlantar. Tanah terlantar adalah tanah yang sudah diberikan hak oleh negara berupa Hak Milik, Hak Guna Usaha, Hak Guna Bangunan, Hak Pakai dan Hak Pengelolaan, atau dasar penguasaan atas tanah yang tidak diusahakan, tidak dipergunakan, atau tidak dimanfaatkan sesuai dengan keadaannya atau sifat dan tujuan pemberian hak atau dasar penguasaannya.

Namun Pengertian Tanah Terlantar ini harus dibedakan dengan pengertian Tanah yang diindikasikan Terlantar, adapun yang dimaksud dengan Tanah yang diindikasikan Terlantar adalah tanah yang diduga

30 Hamdi, Penyelesaian Sengketa Penetapan Ganti Rugi dalam Pengadaan Tanah untukPembangunan Kepentingan Umum (kajian terhadap UU No. 2 tahun 2002), Jurnal IUS, Volume II, 1 April 2014, hlm. 103. tidak diusahakan, tidak dipergunakan, atau tidak dimanfaatkan sesuai dengan keadaan atau sifat dan tujuan pemberian hak atau dasar penguasaannya yang belum dilakukan identifikasi dan penelitian. (Pasal 1 Angka 5 Perka BPN No.4 Tahun 2010).

Perbedaan keduanya terletak pada telah atau tidaknya dilakukan identifikasi dan penelitian terhadap suatu tanah yang tidak diusahakan, tidak dipergunakan, atau tidak dimanfaatkan sesuai dengan keadaan atau sifat dan tujuan pemberian haknya tersebut, sehingga sebelum adanya penetapan suatu tanah dalam kondisi di atas suatu tanah tidak bisa dikatakan tanah terlantar melainkan masih berstatus tanah yang diindikasikan tanah terlantar.

Akibat hukum dari tanah terlantar adalah tanah tersebut jatuh kepada negara sebagaimana diatur dalam Pasal 27 sub a UUPA

Hak milik hapus bila :

a. Tanahnya jatuh kepada negara :

1. Karena pencabutan hak berdasarkan Pasal 18

2. Karenapenyerahan sukarela oleh pemiliknya

3. Karena ditelantarkan

Dalam penjelasan Pasal 27 UUPA, tanah ditelantarkan jika dengan sengaja tidak dipergunakan sesuai dengan keadaannya atau sifat dan tujuan dari pada haknya. ${ }^{31}$

31 Dalam ketentuan pasal ini saya setuju dengan meaning dari Pasal 27 UUPA ini. Hal ini disebabkan untuk mengatasi permasalahan terkait adanya ketimpangan kepemilikan dan penguasaan terhadap tanah. Selain itu demi meningkatkan cara-cara produksi, konsumsi 


\subsubsection{Pembebasan Tanah Dan Pencabutan Hak-Hak Atas Tanah}

Indonesia sekarang dalam suasana pembangunan sebagaimana kita bisa lihat dari kebutuhan akan tanah semakin meningkat. Usahausaha pengembangan perkotaan baik berupa perluasan dengan membuka tempat-tempat pemukiman baru dipinggiran kota maupun usaha-usaha pemekarannya sesuai dengan tata kota senantiasa membutuhkan tanah untuk keperluan tersebut. Seperti pembangunan gedung-gedung sekolah, pasar inpres, puskesmas, dan pelebaran jalan itu semuanya memerlukan tanah sebagai sarana utamanya.

Ada berbagai kepentingan yang kelihatannya saling bertentangan antara satu dengan persoalan tanah dalam pembangunan itu. Di satu sisi pembangunan sangat memerlukan tanah sebagai sarana utama, sedangkan di lain pihak warga masyarakat memerlukan ranah tersebut sebagai tempat pemukiman dan tempat mata pencahariannya. Pembangunan banyak dijadikan sebagai kambing hitam, yang menimbulkan kesan bahwa segala sesuatunya akan menjadi halal bilamana dilakukan untuk dan demi pembangunan sekalipun hal tersebut bertentangan dengan hukum (melanggar hukum). Hal tersebut bertentangandenganasaspembangunan yang berupa asas perikemanusiaan

dan distribusi pangan sehingga mencapai perkembangan dan pemanfaatan sumber daya alam yang efisien. dalam keseimbangan. ${ }^{32}$

Prinsip-prinsip dan ketentuanketentuan hukum haruslah tetap dijadikan landasan sesuai dengan prinsip bahwa negara Indonesia adalah suatu negara hukum. di samping itu juga harus diperhatikan asas-asas kesejahteraan (prosperity) sesuai dengan apa yang menjadi tujuan negara kita untuk mewujudkan masyarakat yang sejahtera atau masyarakat yang adil dan makmur tanpa mengabaikan asas-asas keamanan sehingga stabilitas nasional akan tetap terpelihara.

Berkenaan dengan pengambil alihan tanah penduduk yang akan dipakai untuk keperluan pembangunan menurut ketentuan hukum yang berlaku di Indonesia dapat dibedakan dengan 2 (dua) saluran, yaitu:

1. Pembebasan tanah ialah melepaskan hubungan hukum semula yang terdapat diantara pemegang hak/penguasa atas tanah dengan cara pemberian ganti rugi atas dasar musyawarah dengan pihak-pihak yang bersangkutan. ${ }^{33}$

2. Pencabutan hak-hak atas tanah ialah pengambilalihan tanah kepunyaan sesuatu pihak oleh

32 Abdurrahman, Masalah Pencabutan HakHak Atas Tanah dan Pembebasan Tanah Di Indonesia (Seri Hukum Agraria I ), alumni, Bandung, 1978, hlm.14. (Selanjutnya disingkat menjadi Abdurrahman I).

33 Abdurrahman, Beberapa Aspek Hukum Tentang Masalah Pembebasan Tanah dalam Pelaksanaan Pembangunan, Majalah Orientasi Fakultas Hukum Lampung Mangkurat Th. II No. 4, 1997, hlm. 9. (Selanjutnya disingkat menjadi Abdurrahman II) 
negara secara paksa, yang mengakibatkan hak atas tanak itu menjadi hapus, tanpa yang bersangkutan melakukan suatu pelanggaran atau lalai dalam memenuhi kewajiban hukum. ${ }^{34}$

Bilamana kita meneliti UUPA, Indonesiahanyamengenal "Pencabutan Hak" yang diatur dalam Pasal 18 UUPA. Pencabutan hak atas tanah untuk kepentingan umum merupakan suatu cara untuk memperoleh tanah yang digunakan untuk kepentingan umum, yaitu setelah dilakukanberbagai cara tidak membawa hasil sebagaimana diharapkan sedangkan keperluan untuk pembangunan tanah yang dimaksud sangat mendesak sekali. Adapun yang berwenang melakukan pencabutan hak atas tanah adalah Presiden sebagai Pejabat Eksekutif tertinggi setelah mendengar penjelasan dari Menteri Dalam Negeri, Menteri Kehakiman dan menteri yang bersangkutan yaitu menteri yang bidang tugasnya meliputi usaha yang meminta dilakukannya pencabutan hak atas tanah tersebut.

Kemudian dalam beberapa pasal dalam UUPA ditegaskan pula bahwa hak milik, hak guna usaha dan hak guna bangunan akan hapus karena dicabut untuk kepentingan umum, sebagaimana diatur dalam Pasal 27 sub. a, Pasal 34 sub b dan Pasal 40 sub d. Selain karena pencabutan hak

34 Abdurrahman, Pencabutan Hak-Hak Atas Tanah Untuk Kepentingan Umum, Majalah Hukum, Penerbit Yayasan Penelitian dan Pengembangan Hukum (law Center), No. 4 Tahun ke-II-III, 1976, hlm. 51. (Selanjutnya disingkat menjadi Abdurrahman III) menurut UUPA hak milik, hak guna usaha dan hak guna bangunan akan menjadi hapus karena penyerahan dengan sukarela oleh pemiliknya (Pasal 27 sub a bagian 2) atau dilepaskan oleh pemegang haknya sebelum jangka waktunya berakhir (Pasal 34 sub c dan Pasal 40 sub c). Hak yang demikian ini lazimnya disebut dengan "Pelepasan Hak". Pelepasan hak adalah perbuatan seseorang pemegang hak untuk melepaskan apa yang menjadi haknya secara sukarela setelah kepada diberikan suatu ganti rugi yang layak.

Pembebasan tanah dapat dipandang Sebagai langkah pertama untuk mendapatkan tanah penduduk baik yang akan digunakan untuk kepentingan umum maupun swasta. Menurut Pasal 1 ayat 1 Peraturan MenteriDalamNegeriNomor 15 Tahun 1975 tentang ketentuan-ketentuan mengenai tata cara pembebasan tanah untuk kepentingan pemerintah (yang selanjutnya disingkat menjadi Permendagri No. 15 Tahun 1975), ditegaskan bahwa yang dimaksud dengan pembebasan tanah adalah melepaskan hubungan hukum yang semula terdapat diantara pemegang hak atau penguasa atas tanahnya dengan cara memberikan ganti rugi. Jika kita melihat pasal tersebut, yakni dari pihak penguasa maka pengambilan tanah seseorang adalah sebagai pembebasan (hak) tanah, dimana pihak pemerintah membebaskan tanah yang bersangkutan dari hak dan kekuasaan si pemegang haknya, sehingga tanah 
yang diinginkan benar-benar dari kekuasaannya. Sedangkan dilihat dari sudut pandang si pemegang hak, maka perbuatannya adalah berupa pelepasan hak atas tanah, yaitu si pemegang hak atas tanahnya secara sukarela melepaskan haknya, setelah ia mendapatkan ganti rugi yang layak.

Persoalan mengenai ganti rugi dalam pembebasan tanah adalah menyangkut masalah hak-hak dari pemilik tanah yang tanahnya dibebaskan, sehingga dapatlah dikatakan bahwa unsur uang mutlak harus ada dalam pelaksanaan pembebasantanah (gantirugi). Menurut Pasal 6 PMDN No 15 tahun 1975 telah ditegaskan mengenai besarnya ganti rugi, panitia pembebasan tanah harus mengadakan musyawarah kepada pemilik atau pemegang hak atas tanah dan atau benda atau tanaman yang ada di atasnya berdasarkan harga umum setempat. Jadi berdasarkan Pasal tersebut, untuk menetapkan ganti rugi haruslah diperhatikan 2 (dua) hal yaitu: ${ }^{35}$

a. Penetapan ganti rugi haruslah didasarkan musyawarah antara panitia dengan pemegang hak atas tanah. Di dalam mengadakan penafsiran penetapan besarnya ganti rugi, panitia hendaknya mengusahakan tercapainya persetujuan kedua belah pihak berdasarkan musyawarah

b. Penetapan ganti rugi haruslah memperhatikan harga umum setempat, di samping harus

35 Abdurrahman, Op.cit, hlm. 33 memperhatikan faktor-faktor lain yang mempengaruhi harga tanah.

Tanah-tanah yang dibebaskan dengan mendapatkan ganti rugi, menurut ketentuan Pasal 1 ayat 5 PMDN dapat berupa tanah-tanah yang telah mempunyai suatu hak berdasarkan UUPA dan tanah-tanah masyarakat hukum adat. Jadi perbuatan ini harus didasarkan pada kesukarelaan si pemegang hak.

Istilah pencabutan hak atas tanah ini dikenal atau digunakan secara tegas dalam UU No 20 Tahun 1961 tentang Pencabutan Hak Atas Tanah, sedangkan sebelumnya tercantum dalam Stbl. 1920 No 574 dipergunakan dengan istilah Onteigening menurut arti sesungguhnya hanya berarti pencabutan hak eigendom (hak milik saja sebagaimana halnya yang di cantum dalam Pasal 27 UUDS) akan tetapi istilah Onteigening tersebut diartikan secara luas dalam arti tidak saja pencabutan hak eigendom, akan tetapi meliputi pencabutan-pencabutan terhadap hak-hak lainnya.

Menurut ketentuan hukum yang berlaku berkenaan dengan pencabutan hak ini, maka untuk pelaksanaannya pencabutan hak atas tanah untuk kepentingan umum harus dipenuhinya beberapa syarat :

1. Pencabutan hak atas tanah dapat dilakukan bilamana kepentingan umum benar benar menghendakinya. Unsur kepentingan umum harus tegas 
menjadi dasar dalam pencabutan hak ini. Termasuk dalam pengertian kepentingan umum ini adalah kepentingan bangsa, negara, kepentingan bersama dari rakyat serta kepentingan pembangunan.

2. Pencabutan hak hanya dapat dilakukan oleh pihak yang berwenang menurut tata cara yang ditentukan dalam ketentuan perundang-undangan yang berlaku. Untuk keperluan itu, pemerintah telah menetapkan Undang-Undang No. 20 Tahun 1961 dan berbagai ketentuan pelaksanaan guna mengatur acara pencabutan hak atas tanah tersebut.

3. Pencabutan hak atas tanah harus disertai dengan ganti kerugian yang layak. Pemilik atau pemegang hak atas tanah berhak atas pembayaran sejumlah ganti kerugian berdasarkan harga yang pantas.

\subsection{Upaya Hukum Yang Dapat Dilakukan Oleh Pihak Ketiga Terhadap Tanah Terlantar}

Pasal 4 ayat (1) UUPA menetapkan bahwa atas dasar hak menguasai negara ditentukan adanya macam-macam hak atas permukaan bumi, yang disebut tanah, yang dapat diberikan kepada dan dipunyai oleh orang-orang, baik sendiri maupun bersama-sama dengan orang-orang lain serta badan-badan hukum. hak atas tanah dapat diberikan dan dipunyai oleh orang-orang secara sendiri maupun bersama-sama dengan orang lain, dan kepada badan hukum Indonesia maupun badan hukum asing yang mempunyai perwakilan di Indonesia. $^{36}$

UUPA memberikan pengakuan kepada individu untuk berkedudukan sebagai subjek hak atas tanah (untuk memperoleh hak atas tanah). Jika kemudian hak atas tanah tersebut dihadapkan dengan kepentingan umum atau kepentingan masyarakat maka hak atas tanah perorangan tersebut tidak dapat diabaikan begitu saja tetapi harus mendapatkan ganti rugi. Oleh karena itu hak atas tanah tersebut tidak bersifat absolut tetapi mempunyai fungsi sosial seperti yang disebutkan dalam pasal 66 UUPA, menurut penjelasan umum angka II Nomor 4 UUPA disebutkan fungsi sosial dari hak atas tanah mempunyai arti sebagai berikut :

1. Tidak dibenarkan bahwa tanahnya akan dipergunakan ( tidak dipergunakan) semata-mata untuk kepentingan pribadinya;

2. Penggunaannya tidak boleh menimbulkan kerugian bagi masyarakat;

3. Penggunaannya harus sesuai dengan keadaan dan sifat dari haknya;

4. Penggunaannya tidak saja bermanfaat bagi kesejahteraan dan kebahagiaan pemegang

36 Urip Santoso, Op., Cit., hlm. 206. 
haknya tapi juga bermanfaat pula bagi masyarakat dan negara.

Disediakan berbagai cara untuk memperoleh hak atas tanah untuk diperlukan, yang ketentuanketentuannya disusun dalam suatu sistem yang didasarkan atas kenyataan:

a. Status tanah yang tersedia:

1) Tanah Negara, atau

2) Tanahnya tanah hak.

Berdasarkan kriteria diatas, disusun sistem perolehan baik untuk keperluan pribadi atau usaha maupun untuk kepentingan umum sebagai berikut: ${ }^{37}$

a. Kalau tanah yang tersedia tanah Negara, harus melalui permohonan hak baru;

b. Kalau tersedia tanah hak, harus dilihat yaitu:

- $\quad$ Tergantung pada pemegang haknya apakah bersedia atau tidak;

- Jika pemegang hak bersedia mengerahkan atau memindahkan haknya terlebih dahulu harus memenuhi syarat dan ada persetujuan bersama serta kata-sepakat menghendaki penyerahan tanah yang bersangkutan, berikut imbalannya:
a. Ditempuh acara pemindahan hak.
b. Ditempuh acara pelepasan hak.

37 Budi Harsono, Op., Cit., hlm. 344.
Suatu tanah telah ditetapkan sebagai tanah terlantar maka tanah tersebut akan dikuasai langsung oleh negara yang akan peruntukannya akan digunakan kepentingan masyarakat dan negara melalui reforma agraria. Menurut Pasal 1 ayat (8) Peraturan Menteri Negara Agraria atau Kepala Badan Pertanahan Nasional Nomor 9 Tahun 1999, yang menentukan bahwa:

"Pemberian atas tanah adalah penetapan pemerintah yang memberikan suatu hak atas tanah negara, perpanjangan jangka waktu hak, pembaharuan hak, perubahan hak, termasuk pemberian hak di atas tanah Hak Pengelolaan.'

Tanah yang kewenangan pemberiannya diberikan kepada badan pertanahan nasional adalah Hak Milik, Hak Guna Usaha, Hak Guna Bangunan, Hak Pakai Dan Hak Pengelolaan. Pemberian hak dapat dilaksanakan dengan keputusan pemberian hak secara individual atau kolektif atau secara umum. Pemberian dan pembatalan Hak Milik, Hak Guna Usaha, Hak Guna Bangunan, Hak Pakai Dan Hak Pengelolaan dilakukan oleh Kepala Badan Pertanahan Nasional Republik Indonesia, Kewenangan pemberian hak dapat dilimpahkan kepada Kepala Kantor Wilayah Pertanahan Nasional Provinsi atau Kepala Kantor Pertanahan Kabupaten atau Kota. ${ }^{38}$

38 Urip Santoso, Op., Cit., hlm. 218. 
Ketentuan- ketentuan yang harus diperhatikan dalam permohonan pemberian hak Pasal 4 Peraturan Menteri Agraria atau Kepala Badan Pertanahan Nasional No. 9 Tahun 1999 adalah:

1. Sebelum mengajukan permohonan hak, permohonan harus menguasai tanah yang dimohon dibuktikan dengan data yuridis dan data fisik sesuai dengan ketentuan peraturan perundang-undangan yang berlaku.

2. Dalam hal tanah yang dimohonkan merupakan tanah Hak Pengelolaan, pemohon harus terlebih dahulu memperoleh persetujuan berupa perjanjian penggunaan tanah dari pemegang Hak Pengelolaan.

3. Dalamhaltanahyangdimohonkan merupakan tanah kawasan hutan, harus terlebih dahulu dilepaskan dari statusnya sebagai kawasan hutan sesuai dengan ketentuan peraturan perundang-undangan yang berlaku.

4. Tanah-tanah tertentu yang diperlakukan untuk konversi yang ditetapkan Kepala Badan Pertanahan Nasional Republik Indonesia tidak dapat dimohonkan dengan sesuatu hak atas tanah.

\section{KESIMPULAN}

Berdasarkan permasalahan di pemaparan atas, dapat ditarik beberapa kesimpulan ialah Hakekat dari prinsip kepentingan umum terhadap tanah ialah untuk menciptakan pembangunan yang berlandaskan asas perikemanusiaan dalam keseimbangan sebagaimana diatur dalam UUD NRI tahun 1945. Pembebasan hak atas tanah disebabkan oleh kepentingan umum dan swasta dengan pemberian ganti rugi dan berpedoman pada asas musyawarah. Sedangkan pencabutan hak atas tanah merupakan semangat dari ketentuan Pasal 18 UUPA menggariskan bahwa untuk kepentingan bangsa dan negara serta kepentingan bersama (hanya untuk kepentingan umum) dari rakyat hak atas tanah dapat dicabut dengan memberikan ganti kerugian. Upaya hukum yang dapat dilakukan pihak ketiga untuk dapat memanfaatkan tanah negara (tanah terlantar) ialah melakukan permohonan hak kepada pemerintah (Kantor Pertanahan Provinsi atau Kabupaten/Kota)

\section{DAFTAR PUSTAKA}

\section{BUKU}

Fuady, Munir, 1999. Hukum Bisnis dalam Teori dan Praktik, Cet. II, Citra Aditya Bakti, Bandung.

Idham, H., 2004. Konsolidasi Tanah Perkotaan dalam Perspektif Otonomi Daerah, Cet. I, Alumni, Bandung.

Mahendra, A. A. Oka, 1996. Menguak Masalah Hukum, Demokrasi dan Pertanahan, et. I, Sinar Harapan, Jakarta. 
Marzuki, Peter Mahmud, 2014. Artikel Majalah Ilmiah

Penelitian Hukum, Kencana Perdana Media, Surabaya.

Munandar, M., 1998. Dinamika Masyarakat Transisi, Pustaka Pelajar, Jakarta.

Mertokusumo, Sudikno, 2002. Mengenal Hukum, Cet. III, Liberty, Yogyakarta.

Parlindungan, A.P., 1993. Pencabutan, dan Pembebasan HakAtas Tanah Suatu Studi Perbandingan, Cet. I, Mandar Maju.

Roosadijo, Marmin M., 1979. Tinjauan Pencabutan Hak-Hak Atas Tanah dan Benda-Benda yang Ada di Atasnya, Cet. I, Ghalia Indonesia, Jakarta.

Salindeho, Jhon, 1993. Masalah Tanah Dalam Pembangunan, Sinar Grafika, Jakarta.

Sutedi, Adrian, 2008. Implementasi Prinsip Kepentingan Umum (Dalam Pengadaan Tanah Untuk Pembangunan), Cet. II, Sinar Grafika, Jakarta.

Sumardjono, MariaS.W., TanahDalam Perspektif Hak Ekonomi, Sosial, dan Budaya, Cet. II, Kompas Media Nusantara, Jakarta, 2009.

Soimin, Shoedaryo, 2008. Status Hak dan Pembebasan Tanah, Cet. II, Sinar Grafika, Jakarta.

Santoso, Urip, 2015. Pendaftaran dan Peralihan Hak atas Tanah, Cet. I, Kencana Prenada Media, Jakarta.

Wiguna, Y. Wartaya, SJ, 2004. Tanah Sumber Nilai Hidup, Cet. I, Kanisius, Jakarta.
Abdurrahman, Pencabutan Hak-Hak Atas Tanah Untuk Kepentingan Umum, Majalah Hukum, Penerbit Yayasan Penelitian dan Pengembangan Hukum (law Center), No. 4 Tahun ke-II-III, 1976.

Abdurrahman, Beberapa Aspek Hukum Tentang Masalah Pembebasan Tanah dalam Pelaksanaan Pembangunan, Majalah Orientasi Fakultas Hukum Lampung Mangkurat Th. II No. 4, 1997 ,

Adnyana, Penggunaan Kuasa Menjual Di dalam Peralihan Hak Milik Atas Tanah Melalui Jual-Beli, Jurnal Magister Hukum Udayana (Udayana Master Law Journal), Vol.4, No.1, Edisi Mei 2015, https://ojs.unud.ac.id/index. php/jmhu/article/view/13050, diakses tanggal 20 Oktober 2017.

Eman, Pengadaan Tanah bagi Pelaksanaan Pembangunan bagi Kepentingan Umum, Majalah YURIDIKA, Volume 23, No 1, Fakultas Hukum Universitas Airlangga, Surabaya, Januari April 2008.

Hamdi, Penyelesaian Sengketa Penetapan Ganti Rugi dalam Pengadaan Tanah untuk Pembangunan Kepentingan Umum (kajian terhadap UU No. 2 tahun 2002), Jurnal IUS, Volume II, 1 April 2014. 
Suhirman, Prinsip-Prinsip Pengelolaan Pemanfaatan Tanah Wakaf Guna Peningkatan Kesejahteraan Masyarakat, Jurnal Magister Ilmu Hukum Udayana (Udayana Master Law Journal), Vol. 4, No. 2 : 252-262, Edisi Juli 2015, https://ojs.unud.ac.id/index. $\mathrm{php/jmhu/article/view/17521,}$ diakses tanggal 21 Oktober 2017.

Putu Ade Harriestha Martana, Perlindungan Hukum Bagi Pemegang Sertifikat Hak Milik Atas Tanah dalam Ketentuan Pasal 32 Ayat (2) PP No. 24 Tahun 1997, Jurnal Magister Hukum Udayana (Udayana Master Law Journal), Vol. 3 No. 1 Edisi Maret 2014 https://ojs. unud.ac.id/index.php/jmhu/ article/view/8446, diakses tanggal 21 Oktober 2017.

Rosmidah, Pengakuan Hukum Terhadap Hak Ulayat Masyarakat Hukum Adat dan Hambatan Implementasinya, Jurnal Ilmu Hukum, Volume 3 no. 1, Universitas Jambi, September, 2017.

Winner Sitorus, Kepentingan Umum dalam Perlindungan Paten, Majalah YURIDIKA, Volume 29, No 1, Fakultas Hukum Universitas Airlangga, Surabaya, Januari - April 2014.

\section{Disertasi}

Boedi Harsono, "Masalah Kerangka Persoalan dan Pokok-Pokok Kebijaksanaan Pertanahan Nasional, dalam BF Sihombing, Pergeseran Kebijakan Pengadaan Tanah untuk Kepentingan Pemerintahan dan Swasta (Studi Kasus Pengaturan Pemilikan, Pengusaha Tanah di Provinsi DKIJakarta), Disertasi, Universitas Indonesia, Jakarta, 2004.

\section{Perundang-undangan}

Undang-Undang Dasar Negara Republik Indonesia Tahun 1945

Undang-Undang Republik Indonesia Nomor 5 Tahun 1960 tentang Peraturan Dasar Pokok-Pokok Agraria (Lembaran Negara Tahun 1960 Nomor 104, Tambahan Lembaran Negara Nomor 2043)

Undang-Undang 11 Tahun 2005 tentangPengesahanInternasional Convenant on Economic, Social and Cultural Rights (Konvenan Internasional tentang Hak-hak Ekonomi, Sosial, dan Budaya). 